\title{
Interactive comment on "Application of logistic regression to simulate the influence of rainfall genesis on storm overflow operation: a probabilistic approach” by Bartosz Szeląg et al.
}

Bartosz Szeląg et al.

bszelag@tu.kielce.pl

Received and published: 4 October 2019

Responses to reviewer: Thank you very much for your insightful remarks and comments. We believe that thanks to them the revised manuscript has become much better and more comprehensible. Our responses to the reviewers' comments can be found in the attached pdf file.

Please also note the supplement to this comment:

https://www.hydrol-earth-syst-sci-discuss.net/hess-2019-271/hess-2019-271-AC2- 
Interactive comment on Hydrol. Earth Syst. Sci. Discuss., https://doi.org/10.5194/hess-2019271, 2019.

\section{HESSD}

Interactive

comment 